\title{
MODELING AND DESIGNING HYBRID WIND- SOLAR ENERGY
}

\author{
Eodia Tasik Sedan Lobo ${ }^{1}$, Rombe ${ }^{2}$ \\ ${ }^{1}$ Electrical Engineering Departmen, Christian University of Indonesia Paul Makassar \\ ${ }^{2}$ Electrical Engineering Departmen, Christian University of Indonesia Paul Makassar
}

\begin{abstract}
Fossil energy sources today are getting thinner so that alternative energy sources such as renewable energy are needed. For that, it takes a touch of technology in utilizing such energy sources as sunlight is converted into electrical energy, the wind converted into electrical energy, and so on. These two sources of energy require a high investment cost but do not use fuel, environmentally friendly and long equipment life. Indonesia as an archipelagic State, separated by the sea so that some areas are still connected to electricity interconnected by PLN. The area is generally supplied by Gen set or PLTD which still use fuel oil (BBM) with an expensive price. This first-year research aims to create hybrid energy and hybrid power generation models as an alternative source of environmentally friendly electrical energy, which is carried out at the UKI-Paulus Makassar Laboratory. Modeling of a hybrid system using HOMER (Hybrid Optimization Model for Electric Renewable) version 3.9.1. The result of this research shows that simulation model of hybrid solar energy and energy generation for load requirement of $0.410 \mathrm{~kW}$ or $3.12 \mathrm{kWh} / \mathrm{d}$ is supplied from $P V$ of $0.325 \mathrm{~kW}$ and from Wind Energy $1 \mathrm{~kW}$ with an operating cost of $\$ 1,457$ and an initial investment of $\$ 48,414$. The output power of the inverter is about $0.13 \mathrm{~kW}$ or 130 Watt. Hybrid plants are able to serve consumers effectively.
\end{abstract}

Keywords: Model, Hybrid System, PV, Wind

$* * *$

\section{INTRODUCTION}

Nowadays, one of the energy sources that concerns the government especially and developed countries is solar energy and wind energy because it is easy to get and environmentally friendly. This energy source is known as an alternative energy source. This is very helpful to the government in saving electrical energy because the electricity generated does not use fuel oil (BBM).

The vast territory of Indonesia which is uses electricity generation that is separate from the interconnection system. Thus, an alternative separated by land and sea becomes one of the unequal factors of PLN's electricity service so that the archipelago energy source that can serve rural communities is needed. $\mathrm{P}$ this has an impact on technological developments and rural economic growth. Along with these developments, the need for electrical energy also continues to increase. However, related parties have limitations and require substantial investment to build new power plants such as Diesel Power Plant (PLTD) or Generator Set (Gen set) to meet the needs of the community. Seeing the problems that influence the economic growth of rural communities, the constraints on investment costs, operational costs and fuel costs, this research is made simulation model of a hybrid power plant that is a combination of Solar Power Generation (PLTS) with Wind Power Plant.

\section{LITERATURE REVIEW}

A solar cell known as a solar cell or photovoltaic cell is a semiconductor device that has a large surface and consists of a series of $\mathrm{p}$ and $\mathrm{n}$ diodes that can convert sunlight energy into electrical energy. (Yuliarto, 2006).
Solar cells are prepared by combining $\mathrm{p}$ and type silicon type n. p silicon is positive due to electron deficiency whereas silicon type $n$ is silicon which is negative due to excess electron when receiving (subjected) solar radiation (in the form of a photon) in both ( $\mathrm{p}$ and $\mathrm{n}$ type node) is positive (hole) And negative (electron). This causes the creation of polarization (polarization) where the hole moves toward the $\mathrm{n}$ type silicon. By connecting both types of silicon (type $\mathrm{p}$ and type $\mathrm{n}$ ) through an external conductor there is a potential difference between the two and direct current flow. (Abu Bakar et al., 2006).

Understanding the photovoltaic itself is a process of converting light into electrical energy. Therefore the field of research concerning solar energy is often also known as photovoltaic research. The word photovoltaic comes from Greek photos meaning light and Volta which is the name of the physicist from Italy who invented the electric voltage. So that language can be interpreted as light and electric photovoltaic. (Yuliarto, 2006)

\section{Photovoltaic Solar Power System}

Solar photovoltaic power systems commonly used for lighting are individual systems or more often known as a solar home system (SHS).

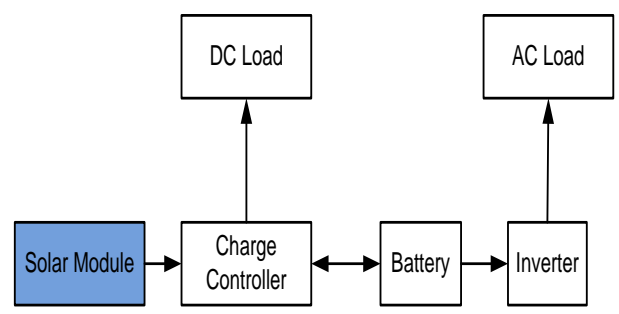

Fig 1: Block diagram of a simple PLTS system 
From Figure 1 it is explained that the energy from the sunlight that is converted into electrical energy by the module will be supplied to the controller charger to adjust the charging of electrical energy in the battery. From this charger, controller can also be directly used for the direct current load (DC Load) or directly into the inverter to be converted into AC current voltage. Furthermore, the electrical energy generated by the battery will be converted by an inverter from a direct current voltage (DC) to an alternating current voltage (AC) so that it can be utilized on AC Load current loads.

The most dominant meteorological conditions in the design of the SHS system are the amount of daily radiation (Wh / $\mathrm{m} 2$ day), as well as ambient temperature, while the humidity and speed of the wood/wind are not very influential. (Abu Bakar et al., 2006).

\section{Battery Capacity}

To ensure the system to operate properly and in accordance with the needs of the load, it should be taken into account the condition of autonomous weather (autonomy days) which is generally calculated for 5 days. To calculate battery capacities using the following equation:

$$
C b=\frac{E_{b} \times d}{V \times K_{b}}
$$

with:

$\mathrm{Cb}=$ Battery Capacity

$\mathrm{E}_{\mathrm{b}}=$ energy required load in a day (W-hour)

$\mathrm{V}$ = working voltage of batteries

$=12$ Volt or 24 Volt

$\mathrm{d}=$ number of days without

Radiation $/$ year $=5$

$\mathrm{K}_{\mathrm{b}}=$ efficiency of charging and discharging batteries

$=0.8$

\section{Wind Power Plant (PLTB)}

The Wind is the air that moves in our natural surroundings because there is a movement of air that is not horizontal (vertical or tilted) to the ground surface then the more precise formula is caused by the movement of air (relative) to the surface of the earth. The main cause of the occurrence of wind is the temperature difference, this difference causes the emergence of the pressure difference from high air pressure to lower air pressure, this air movement is called the wind, is flattening the air pressure, so the higher the air pressure the stronger the wind flow.

In turn, the air pressure difference is the result of solar irradiation in relation to the nature of the earth's surface between one place and another, such as the difference in the degree of reflection. In addition, the rotation of the earth on the axis also plays a role in the process of wind. On a large scale or general circulation (the average wind circulation in the earth), air circulation is generated by warming up more on the earth's surface in the equator than the poles, the hot air from the tropics becomes lighter and moves up to
Bottom layer. The wind speed that can be used as a wind power plant is wind grade 3-8 with a speed of 3, $4-20.7 \mathrm{~m} /$ S.

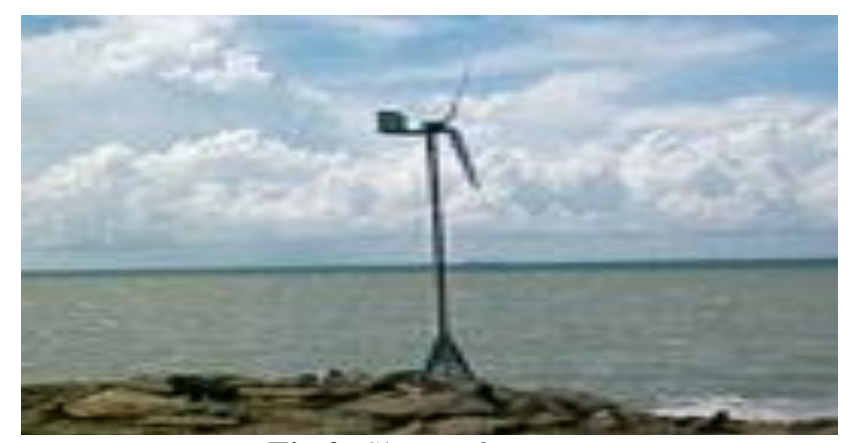

Fig 2: Shape of PLTB

Electric Wind Power (PLTB) is one of the renewable energy power plants that is environmentally friendly and has a good working efficiency when compared with other renewable energy power plants.

The working principle of PLTB is to utilize the kinetic energy of the wind into the effective area of the turbine to rotate the vane/windmill, then the rotary energy is passed to the generator to generate electrical energy.

Converting electrical energy to this PLTB requires a continuous wind blow to turn a wind turbine. This rotating wind turbine will be connected to a mechanical transmission (optional) to produce higher or lower rotation and then rotate the generator. Power in this PLTB system consists of several kinds, can be classified into (Burton T, et al 2001):

Wind Power (PW)

Wind Turbine Power (PA)

Power Generator (P Gen)

\section{Wind Power}

Wind power is the amount of energy that can be generated by the wind at a certain speed that hits a windmill with a certain area. This wind power formula can be written by:

This wind power formula can be written by:

$$
\mathrm{P}_{\mathrm{w}}=\frac{1}{2} \mathrm{x} \rho_{\mathrm{a}} \mathrm{xAx \textrm {V } ^ { 3 }}
$$

with:

$\rho_{\mathrm{a}}$ : wind density at times certain $(1.2 \mathrm{~kg} / \mathrm{m})$

$\mathrm{v}$ : wind speed at any given time. $(\mathrm{m} / \mathrm{s})$

A: the area of wind sweep (m2)

The total area of wind sweep can be searched with the following formula:

$$
\mathrm{A}=\pi \cdot \mathrm{r}^{2}
$$

with:

A: the area of wind sweep $\left(\mathrm{m}^{2}\right)$

$\mathrm{r}$ : The radius of a turbine circle/turbine length (m) 


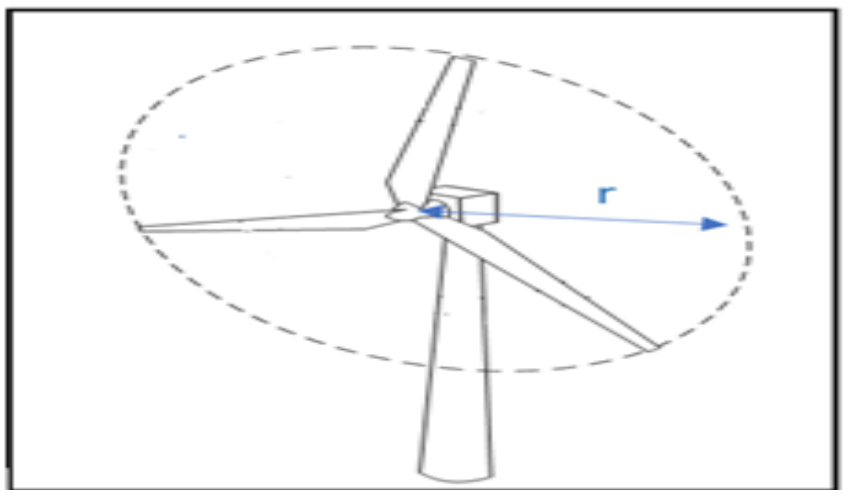

Fig 3: Turbine model with radius $r$

\section{Wind Turbine Power}

The power of a wind turbine (PA) is the amount of mechanical energy that can be generated by the wind turbine rotor due to the power gained from wind gusts. Wind turbine power is not the same as wind power because wind turbine power is affected by power coefficient. This wind power formula can be written by:

$$
\begin{aligned}
& P_{A}=\frac{1}{2} x C_{p} x \rho_{a} x A x V^{3} \\
& P_{A}=C_{p} x P_{w}
\end{aligned}
$$

with:

$c_{p}:$ Power coefficient

The design of wind power plants usually has a power coefficient $\left(c_{p}\right)$ which has a value below the cost of Betz law, due to losses such as copper loss, iron loss, bearing loss, and others. The magnitude of this $C_{P}$ value has a value between $0-0.6$ and also depends on the type of turbine to be used.

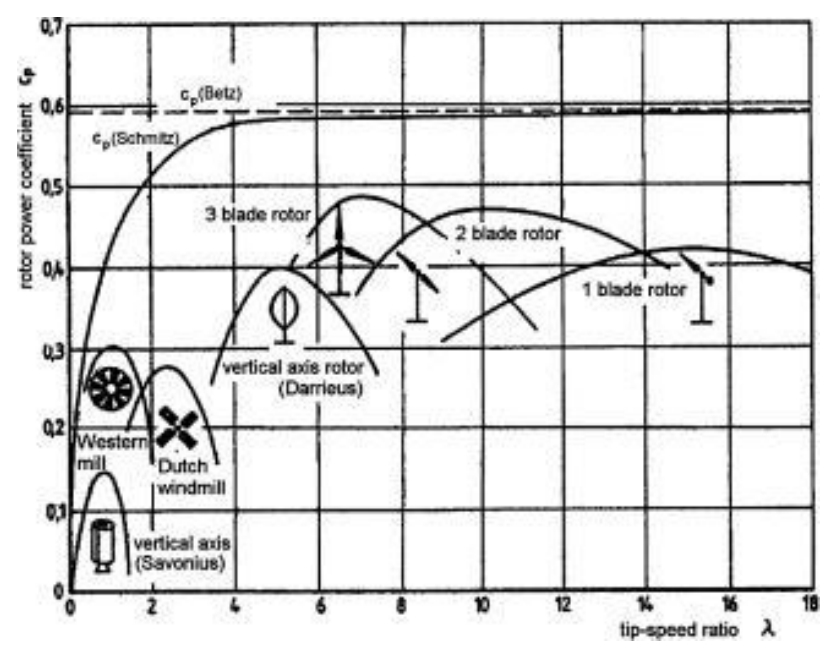

Fig 4: Relation of turbine rotor power coefficient with speed ratio

\section{Power Generator}

Power generator (P gen) is the amount of electrical power that can be generated by the generator due to the rotation of the rotor generator coupled with the turbine shaft. The magnitude of this generator depends on the efficiency of the generator and the efficiency present in the mechanical transmission so that the power generators can generate is calculated by:

$$
\text { Pgen }=\frac{1}{2} \times C_{p} \times \rho_{a} \times A \times V^{3} \times \eta_{\text {gearbox }} \times \eta_{\text {gen }}
$$

with:

$\eta_{\text {gearbox }}:$ Efficiency gearbox /

Mechanical transmission

$\eta_{\text {gen }} \quad$ : Generator efficiency

From equation (4), (5) and (6) above it are concluded that the electrical power generator can generate, then used for electrical equipment is not proportional to the wind power obtained. The difference between the power generated by the wind and the power generated by the generator is very large. This is due to the power coefficient, gearbox efficiency, and generator efficiency.

\section{Hybrid Plant}

The term hybrid is defined by the use of two or more power plants with different energy sources, generally used for the captive of Wind Power Generation, so as to obtain synergies that provide economic and technical advantages which mean the reliability of the supply system.

The main purpose of a hybrid system is basically to try to combine two or more energy sources (generating systems) so that they can cover each other's weaknesses and can achieve supply reliability and economic efficiency in certain load types.

Type load (load profile) is an important keyword in the hybrid system. For each different load profile, a hybrid system with a certain composition is required, in order to achieve the optimum system. Therefore, system design and system sizing play an important role to achieve the targets made hybrid system. For example, a relatively constant load profile for 24 hours can be efficiently and economically supplied by a Wind Power Plant (with suitable capacity), but the load profile where the use of electricity during the day differs considerably compared to the night, will make use of the Wind Power Plant alone is not optimum.

The following is a typical load profile for rural electricity consumers that is at peak load, the use of Wind Power Station reaches the optimum point, but at base load, the efficiency of the Wind Power Plant is greatly reduced. On load profile like this hybrid system is very useful. Hybrid systems can involve 2 or more power generation systems, such as PLTS-Wind

Power Plant, PLTS-Micro hydro, Micro Hydro Power Wind and so on. This system is commonly used on captive Wind / isolated grid (standalone) power plants, is Wind Power Plant which is not interconnected). Combination or Hybrid PVWind Power Generation will increase the storage of electrical energy to Accu in order to be able to provide sufficient electrical energy, so it is necessary to design the 
needs of batteries adapted to the needs of this hybrid system, however, required a considerable initial investment when compared to generators Others like Gen set, but for the long term, Hybrid PV-Power System Wind Power more saves the $\mathrm{O} \& \mathrm{M}$ cost, and the cost of fuel is not there.

\section{RESEARCH METHOD}

Implementation of research conducted to make simulation model of hybrid energy generation wind with solar energy are:

a. Create a hybrid circuit block diagram, as shown in Figure 5 for easy modelling of the circuit

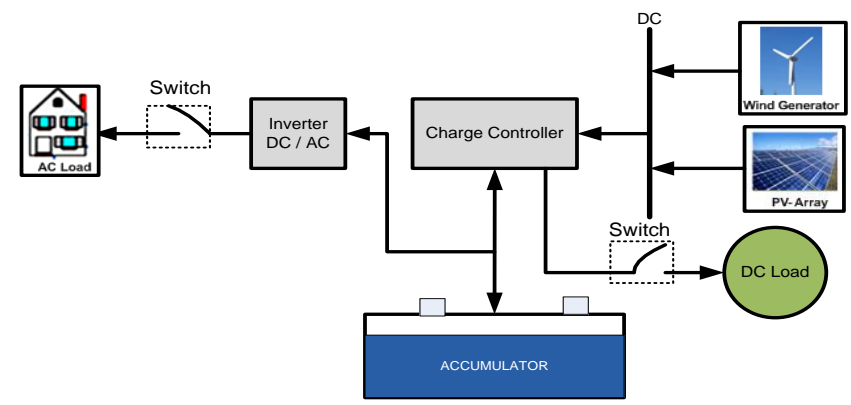

Fig 5: Block hybrid system of Wind Energy and Solar Energy

b. Create a Simulation model

At this stage, the researcher prepares the Homer software and installation as shown in Figure 6. Next, compile the hybrid generator model in a schematic form based on the planned load requirement. In this simulation, the planned load is $3.12 \mathrm{kWh} / \mathrm{d}$ or $0.41 \mathrm{~kW}$ as in figure 6.

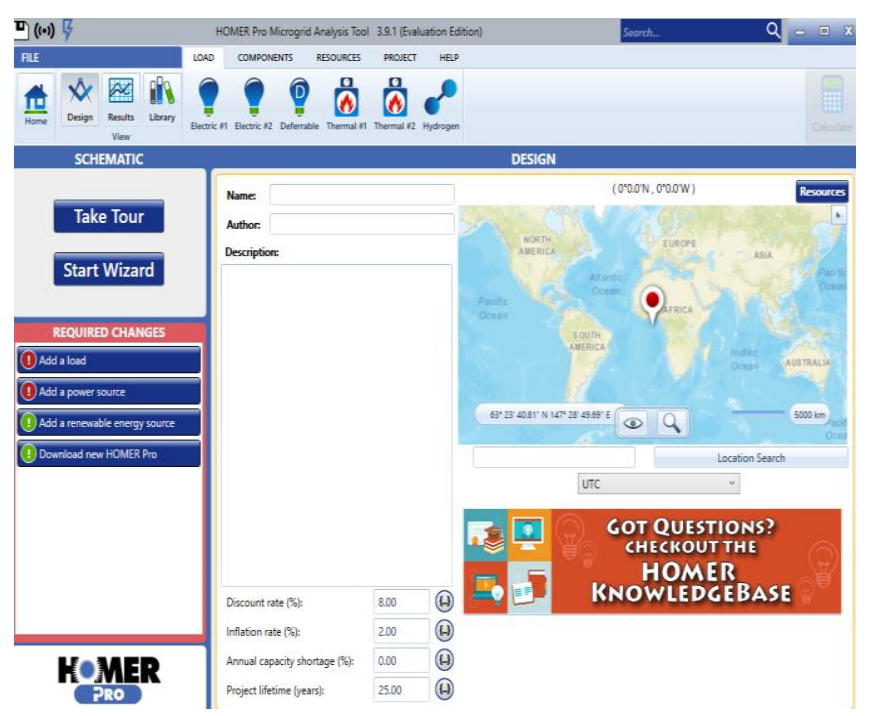

Fig 6: Homer Pro 3.9.1 Application Display on the Windows screen

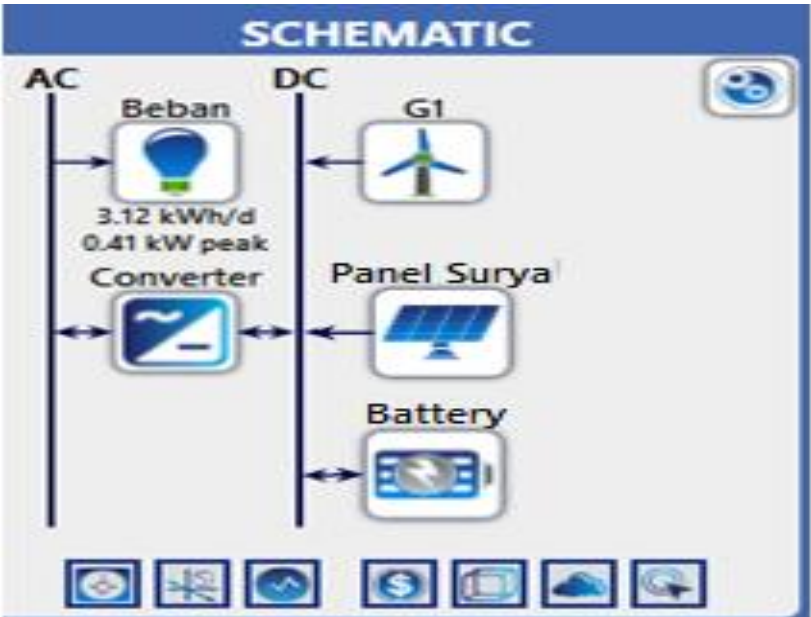

Fig 7: Hybrid System Schematic model in Homer Pro Application V3.9.1

c. Runningthe simulation to get total power supply from solar energy and wind energy.

d. Compile reports

\section{RESULTS AND DISCUSSION}

Modeling of solar energy hybrid generator with the energy of the wind that has been made in Homer Pro V3.9.1 software then the first thing required is load data as in figure 8.

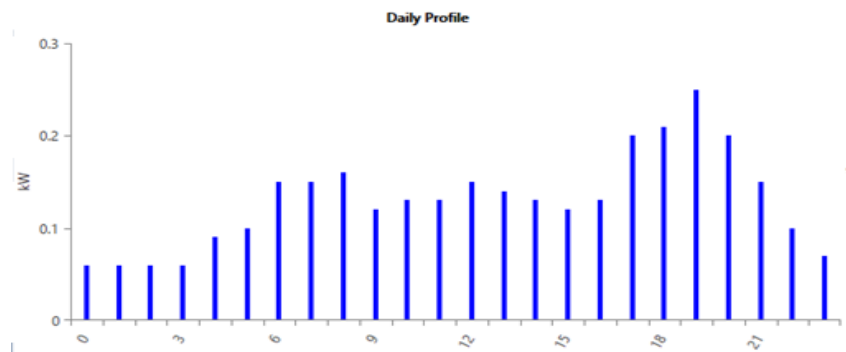

Fig 8: Profile Load in Homer Pro Software

The daily load conditions shown in Figure. 8 can be explained that the average electrical energy requirement for a day is $0.13 \mathrm{~kW}$ or 130 Watt. At $17.00-20.00$ the need for electrical energy is very large or known peak load occurs, and at 23:00 to 05:00 the minimum electrical energy needs. From these conditions, the load data becomes the determinant in determining the energy capacity of electricity that can be supplied by PLTS and PLT-Wind.

Based on the schematic image of the hybrid system in Figure 7 created in the Homer application V3.9.1 consists of:

- G1 as a Wind Turbine coupled with a DC generator as a power plant power plant

- Solar panels as Solar power plants

- Battery as a storage of electrical energy from two sources of electrical energy

- DC bus or DC bus bar as the connector of two sources of electrical energy at direct current voltage 
- Converter as an alternating current voltage converter (AC) to direct current voltage (DC) or DC voltage to DC voltage (AC)

- Load as electricity used by consumers.

- Bus AC or Bus bar AC as a liaison of two sources of electrical energy at alternating current voltage.

Simulation results with Homer Pro software in accordance with the schematic model that has been made is obtained as in figure 9
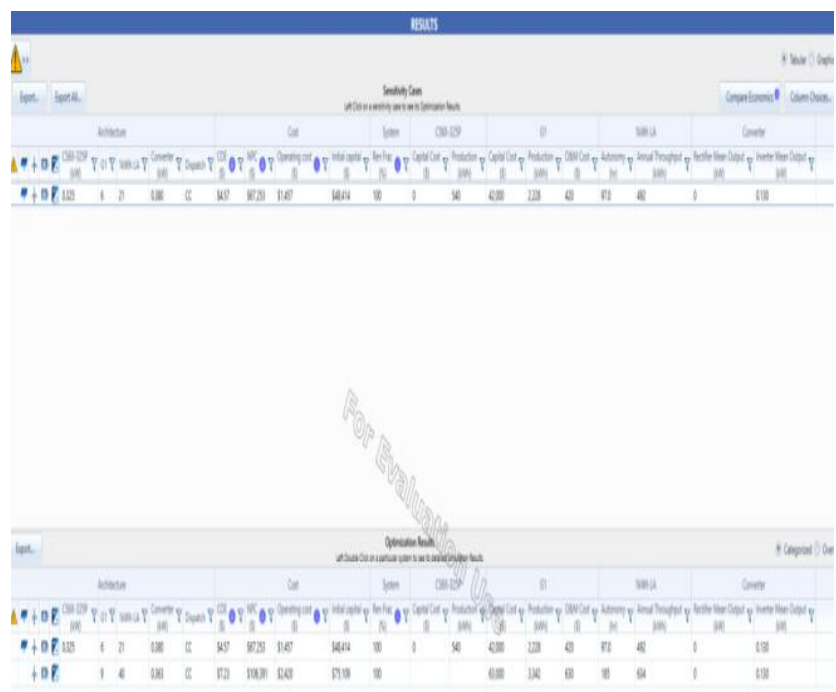

Fig 9: Simulation results with Homer Pro Software V3.9.1

Based on the simulation model that has been run it can be explained that:

a. For a combined PLTS with PLT-Wind using Battery and converter requires an operating cost of $\$ 1,457$ with an initial investment of $\$ 48,414$. The output power of the inverter is $0.13 \mathrm{~kW}$ or $130 \mathrm{Watt}$

b. For PLT-Wind itself using Battery and Converter requires an operating cost of $\$ 2,420$ with an initial investment of $\$$ 75,109 . The output power of the Inverter is $0.13 \mathrm{~kW}$ or 130 Watt

From the above two conditions, a combination of PLTS and PLT-Wind is chosen at point (a) with investment and operational cost cheaper than the point (b) for output power from the same inverter.

\section{CONCLUSION}

- The simulation model of hybrid energy generation wind and solar energy using Homer Pro V3.9.1 application program has been made and can run well

- The planned power for a solar power plant is $325 \mathrm{Wp}$, while a $1 \mathrm{~kW}$ power plant is capable of generating 540 $\mathrm{kWh}$ of electricity from PLTS and 2,228 kWh from PLT-Wind

- The total power generated by the Hybrid Generator is the total Inverter power output of $0.13 \mathrm{~kW}$.

\section{ACKNOWLEDGMENT}

This study is a Research Competitive Grant Number: DIPA 1491/K9/KT.03/2017dated $26^{\text {th }}$ April 2017, for that we would like to thank DitLitabmas that gives research funding.

\section{REFERENCES}

[1]. Burton T, Sharpe D, Jenskin N, Bossanyi E. 2001. Wind Energy Handbook. New York: Wiley.

[2]. El-vice, M. M. 1984. Power plant Technology. Mc Graw-Hill Book Company, Singapore

[3]. Gray Davis, June 2001, A guide to photovoltaic (PV) system design and installation, California, Regional Economic Research, Inc.

[4]. Lubis, Abubakar, and Sudrajat, Adjat. 2006. Solar Electricity photovoltaic. BPPT PRESS, Jakarta. on September 15, 2010

[5]. Liem Ek Bien, Ishak Kasim \& Wahyu Wibowo, August 2008. Design of Hybrid Solar Power System with PLN Electric Nets for Urban House, JETRI, Trisakti University, Jakarta, accessed on July 23, 2010

[6]. Matthew Sau, 2013. Design Wind energy and solar energy generation as an energy-efficient energy, Adwidia, Vol. 2013

[7]. Rahadian Muda S, 2009. Utilization of Solar Cells as Power Supply Mechanical Cooling System On Fishing Boats, Shipping Techniques, ITS Surabaya, Accessed August 2, 2010

[8].Yuliarto B, 2006. Solar Energy: Alternative Energy Sources of the Future in Indonesia, Science and Technology News. 2006. Retrieved June 12, 2012

[9]. Agus Adria and Tarmizi, 2015. Model Hybrid PVGenset Applications on Off-Grid System. National Seminar and Electro Engineering Expo 2015

[10]. Medugu, D. W. \& Michael, E., 2014, Integrated Solar Wind Hybrid Power Generating System for Residential Application, Global Journals Inc. (USA) Online ISSN: 2249-4596 \& Print ISSN: 0975-5861

[11]. Homer, Hybrid Optimization Model for Electric Renewables., HOMER Pro Software V3.9.1., www.homer energi.com., (2016) 